\section{Herman Bang som teaterjournalist og -essayist}

\section{En præsentation af forskningsprojektet \\ Herman Bangs teaterjournalistik og -essayistik - en antologi}

Afdr. phil. Knud Arne Jürgensen, seniorforsker ved Det Kongelige Bibliotek

$\mathrm{F}$ orskningsprojektet Herman Bangs teaterjournalistik og-essayistik - en antologi udføres på Det Kongelige Bibliotek indenfor den ordinære forskningstid suppleret med en portion eksterne forskningsmidler modtaget fra Kulturministeriet af de såkaldte UMTS-midler, der er stillet til rådighed for biblioteket fra og med indeværende finansår. Lag mig indledningsvis begynde med en kort historik omkring Herman Bang og hans teaterjournalistik.

I 1878 udkommer Bangs allerførste teaterkritik i Morgentelegrafen, hvilket fik Vilh. Topsøe på Dagbladet til omgående at invitere ham over som skribent på sin avis. Da Morgentelegrafen gik ind kort efter dette tilbud var blevet fremsat, var sagen klar for Bang og han flyttede hurtigt ind på Dagbladet, hvor han nu for alvor indledte sin livslange journalistiske virksomhed. I disse første skribentår skabte han tillige sine første dramatiske arbejder for Folketeatret.

Bangs parallelle karriere som teaterkritiker, teateressayist og dramatiker tager derefter for alvor fart, blandt andet med nogle nyskrevne stykker, som blev opført på Casino Teatret, Det Kongelige Teater og ved forskellige Privatforestillinger, foruden en imponerende feuilletonmæssig produktion i især Nationaltidende.
I disse tidlige år udkommer desuden værkerne Realisme og Realister, Kritiske Studier og Udkast og Herhjemme og derude, der alle er rige på teatermæssige emner. Desuden udkommer i denne tid novellesamlingen Tunge Melodier og romanen Håblose Slagter foruden fem originale småstykker skrevet for de Københavnske privatteatre samt en række oversættelser af både dramatiske og litterære arbejder efter blandt andre Honoré de Balzac. Endelig fuldender Bang i disse første forfatterår romanen Fadra. Alt dette blev produceret, udgivet og opført inden hans fyldte 25. år.

\section{At Herman Bang var en uhyre} produktiv teaterlitterær ildsjæl i løbet af disse tidlige skribentår bliver her mere end tydeligt. Men at han også var overordentlig velorienteret i sin teaterjournalistik og teateressayistik er i denne sammenhæng endnu mere bemærkelsesværdigt. Han efterlader fra de allerførste journalistår stort set ingen teatermæssige emner og områder ubehandlede i disse første år af det moderne gennembruds tid.

I forbindelse med min tidligere teater-musik- og ballethistoriske forskning har jeg gennem de sidste år med jævne mellemrum været i kontakt med Bangs teaterjournalistik og altid med stort og inspirerende udbytte.

Dette var ikke mindst tilfældet i forbindelse med Det Kongelige Biblioteks store temaudstilling "Det Moderne Gennembrud" i 2002, hvor jeg var faglig ansvarlig for redaktionen af udstillingens afsnit om teatret i det moderne gennembruds tid.

Det var måske derfor i denne mere end nogen anden sammenhæng, at idéen om en samlet udgivelse af et repræsentativt udvalg af Herman Bangs teaterkritik og teateressayistik i form af en antologi med 
en perspektiverende teaterhistorisk indledning for alvor tog form.

Hovedbaggrunden for dette projekts undfangelse var dog først og fremmest den omstændighed, at det på trods af en række vigtige forskningsbidrag i nyere tid, stadig ikke er almindeligt kendt, at den unge Herman Bangs offentlige debut faktisk skete som sceneinstruktør, samt at han nåede at instruere og iscenesætte næsten 80 dramatiske værker.

Bangs indgående arbejde med disse mange forestillinger blev netop ansporet af hans eget omfattende arbejde som teaterkritiker og teateressayist. Lige fra sine unge år skrev han - ofte under mærke - talrige overordentlig interessante artikler, hvoraf flere i dag fortjener at blive genoptaget, belyst, analyseret og kommenteret.

Det er i disse artikler tydeligt, at det ikke blot var det praktiske instruktørarbejde på teatret, men også den omfattende essayistik om teatret og hele scenekunstens væsen, som ansporede Bang til hans efterfølgende store forfatterskab.

Det som dog måske mest lå Herman Bang på sinde med sin teateressayistik, var nok at understrege, at naturalisme mere udgør en kunstform snarere end en æstetisk tendens - med andre ord: en art dramatisk sandhedskunstskole. I sine mange teatermæssige essays er det derfor lige så meget Herman Bangs fine blik og sans for scenekunstens detalje som hans ønske om at trække de store linier op, der er det fremtrædende.

Det samme gælder for hans dramaturgiske kritik og de mange indgående sanger- danser- og ikke mindst skuespillerportrætter, der i flere tilfælde står tilbage som nogle af datidens absolutte teaterkritiske højdepunkter.

Bangs teateressays er tillige rigt facetterede ved deres indgånde overvejelser om teatrets, instruktørens, skuespillerens, kritikerens og publikums funktioner, og de indgående analyser han fremlægger af såvel trykte dramatekster som egentlige sceniske forestillinger. Alle aspekter af teaterprocessen i det moderne gennembruds tid er her blevet gennemanalyseret af en af datidens førende teatermænd og litterater.

Min kommende Bang-antologi søger at medtage alle væsentlige teaterkritiske og dramaturgiske artikler fra Bangs hånd, som de findes publiceret i løbet af 33 år i omtrent 40 aviser og tidsskrifter lige fra Bangs journalistiske debut i 1878 og helt frem til hans sidste teateriscenesættelser i 1911 kort før hans død i 1912. Desuden medtager antologien også et par enkelte artikler, der blev udgivet posthumt.

Alene antallet af disse teaterartikler og essays er enormt, men hvad der måske er endnu mere bemærkelsesværdigt, er nok den kendsgerning, at der under mit arbejde på dette projekt allerede til dato er fremkommet et stort antal hidtil helt ukendte og uregistrerede arbejder fra de tidligste forfatterår.

Disse nu genfundne artikler repræsenterer meget nyt og godt læsestof for såvel Bang-forskningen som Bang-bibliografien. Alene i den sidste tid er der således i gennemsnit fremkommet en til to artikler om ugen, der ikke tidligere har været behandlet i Bang-litteraturen eller registreret i Bang-bibliografien (her sigtes primært til Anette Gants og Lene Møller Jensens store og fortjenstfulde Bang-bibliografi fra 1978, der desværre stadig foreligger utrykt).

En samlet, og annoteret udgivelse af disse mange både kortere og længere essays og teaterkritiske artikler vil utvivlsomt kunne bidrage til belysningen af en række vigtige forudsætninger ikke alene for Bangs senere berømte forfatterskab, men også kaste 


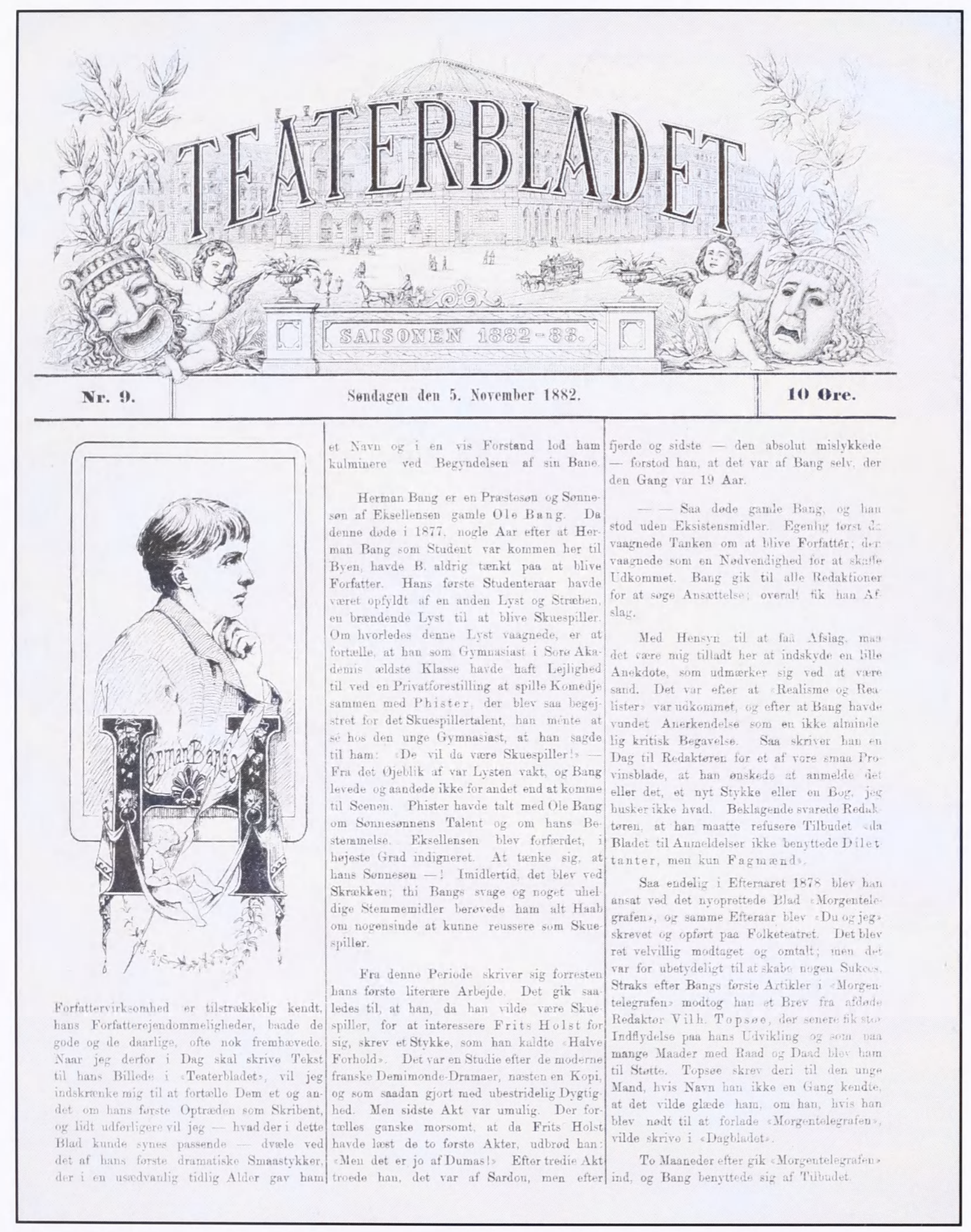

Forsiden af Teaterbladet den 5. november 1882 med den forste store biografiske artikel om Herman Bang. Illustrationen viser et ungdomsportrat af Herman Bang baseret på Peter Mosts forografi fra 1880. (Det Kongelige Bibliotek). 
et interessant teater- og receptionshistorisk lys over hele den moderne gennembruds tid. Udgivelsen vil derfor blive forsynet med en omfattende og perspektiverende teaterhistorisk indledning, der placerer Bang som essayist i tidens teaterhistoriske kontekst; helt konkret vil antologien blive inddelt i 4 bind, hvoraf projektets første etape vil dække de første ca. 10 års teaterkritiske og teateressayistiske produktion.

Som eksempel og mundsmag på en af disse tidlige og hidtil nærmest helt ukendte Bang-artikler, følger her et mindre uddrag. Det er samtidig en af de artikler, hvormed jeg selv for første gang stiftede kendskab med denne forfatters eminente teateressaystik.

I forbindelse med min forskning i balletmester August Bournonvilles (180579) liv og virke faldt jeg for en del år siden over en artikel i Nationaltidende, hvori Bang omhandler Den Kongelige Danske Ballets dengang meget prekære situation i årene lige efter Bournonvilles død. Balletten var på dette tidspunkt i fare for helt at sygne hen, men her trådte Bang resolut til og publicerede et overordentligt velformuleret forsvar for opretholdelsen af denne kunstart på nationalscenen.

I sin faste ugentlige feuilleton $\mathrm{i}$ Nationaltidende, som udkom med fællestitlen Vekslende Themaer, gjorde han den 6. maj 1883 sig til talsmand for disse bemærkelsesværdige kulturpolitiske synspunkter omkring balletten og dens eksistensberettigelse på Nationalscenen:

“...Det er min Overbevisning, at de allerfleste have set meget ensidigt og meget uretfærdigt paa Balletten. For mig er den ene Kunst ikke lavere end den anden, naar dens Ramme tilla- der Mennesket at tale om sig selv. Jeg hører ganske vist straks Folk raabe: Hvad [ballet-vaudevillen] "Fjernt fra Danmark" fortæller af menneskeligt? Men Raabene overbevise mig ikke. Jeg paastaar tværtimod at de fleste af de yngre iblandt os forstaar akkurat ligesaa meget af den romantiske Ballet som af den romantiske Digtning af samme Rang. Vi staa dem begge lige fjernt og lige nær.

Det er sikkert i "Et Folkesagn", i "Napoli", i "Valdemar" Ting af saa stor malende Virkning, at de besidde hele deres gamle Magt over Sindene. Og de besidde den, fordi de give virkelige Menneske-Konflikter, Bevægelser, Situationer og Lidelser Form og Udtryk. Thi dette er den eneste Maade, hvorpaa Kunsten varigt rører os. Naar meget andet i den Bournonvilleske Ballet er falmet og forekommer os for skruet, smagløst og absurd, da beviser dette ikke, at Balletten bør dø, blot fordi selve Bournonville, den største Balletdigter i Norden, ikke formaar at lade den leve udover sit eget Liv. Thi Bournonville skrev ikke Balletter for alle Tider, men for $\sin$ Tid. Hans Ballets Magt var det, at en Romantiker skrev Stykkerne, instruerede og uddannede; og intet Steds i den danske Kunst har Romantiken udviklet sig helere, heller intet Steds saa ensidigt som her.

Men nu er Romantiken foreløbig død. Saa har man heller ikke Brug for denne romantiske Ballet. Netop - men derfor behøver dog ganske bestemt ikke Balletten overhoved at dø. Det vilde ogsaa her være paa Tiden istedet at skabe det nye. 


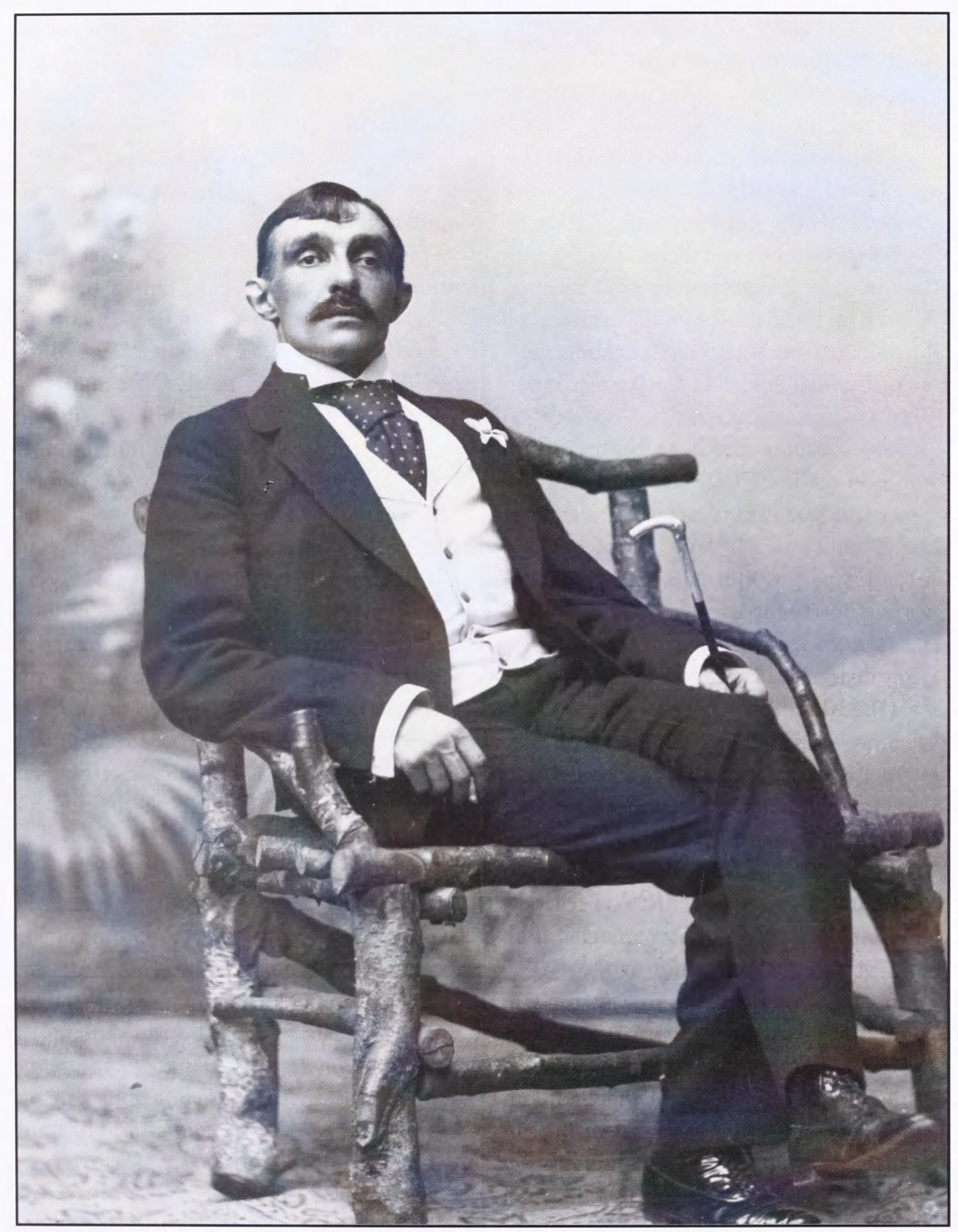

Den modne Herman Bang (1857-1912), fotograferet af Heinrich Tonnies omkring år 1900. (Det Kongelige Bibliotek). 
Ingen af vore Kunstarter rummer mere Dygtighed. Disciplinen er maaske rokket, men den er i al Fald ikke gaaet til Grunde. Her er et fast, et udmærket Stof, hvormed der kunde arbeides. Den, der vilde skabe de nye Former for Balletten, vilde finde udmærkede Redskaber. [...]

\section{Balletten maa vende tilbage}

til Livet, d. v. s. til Folkelivet, til at male Billeder, Sæder og vekslende Skikke. Dér vil findes den rige Mark for ogsaa gjennem Dansen at udtrykke det menneskelige Livs Bevægelser.

Saaledes som man nu lader Balletten sygne hen, handles i hvert Fald uforsvarligt. Der gjøres ikke en Gang Nytte for Pengene, og en Theaterstyrelse, som ellers saa fortræffeligt ved at varetage den økonomiske Side af Tingene, burde ikke tillade dette Spild af Summer. Til alene at medvirke i Operaer er BalletPersonalet efter vore Forhold altfor stort og meget for kostbart. [...]

Saaledes synes mig af mange Grunde Spørgsmaalet om Balletten at trænge sig frem til Diskussion og Bevægelse. Foreløbig kan man glæde sig over, at vi har en koreografisk Kunst til at redde vore Operaer. Hvad vi ikke have i Struberne, "glæde vi os ialfald over endnu at have i Benene" - indtil en smuk Dag Bournonvilles sande Arv, nemlig et udmærket Korps og en mesterlig Skole, er forvitret og ødelagt ved Lediggang og Mangel paa Anvendelse..."

At Bang ikke blot var en fremragende teaterkender og -iagttager, men en ligeså eminent kulturpolitisk skribent fremgår her med al ønskelig tydelighed. Den kommende Bang-antologi vil med sit fyldige udvalg af de væsentligste teaterjournalistiske artikler og essays fra Herman Bangs hånd således utvivlsomt kaste nyt og interessant lys over en væsentlig periode i dansk teater- og musikhistorie.

\section{Anvendt litteratur}

Amsinck, Hanne: Sceneinstruktoren Herman Bang og det franske symbolistiske teater, Kbh., Gad, 1972.

Bang, Herman: Reportager; red. af Claes Kastholm Hansen, [Kbh.], Gyldendal, 1983.

Bang, Herman: Herman Bangs forste journalistik; [red. af] Hans Andersen, [Viby J.], Centrum, cop. 1981.

Bang, Herman: Teaterindtryk fra Rusland 1911, Århus, Arkona, 1979.

Bang, Herman: Kobenhavnske Skildringer: "Vekslende Themaer" 1879-1883; [Udvalg, Noter og Efterskrift af Cai M. Woel], Kbh., Gyldendal, 1954.

Bangsk 2003: Herman Bang som sceneinstruktor; red. af Lars Muhl og Gert Posselt, Kbh., Reitzel, 2003.

Borg, Mette: Sceneinstruktoren Herman Bang, teatersyn og metode, [Kbh.], Nyt Nordisk Forlag i samarbejde med Selskabet for Dansk Teaterhistorie, 1986.

Jacobsen, Harry: Den unge Herman Bang, Mennesket, Digteren, Journalisten og hans By, Kbh., H. Hagerup, 1954.

Jørgensen, John Chr.: Jeg, der kender pressens melodier - : Herman Bangs journalistik, Århus, Ajour, 2003. 